\title{
Study of Relationship of Anemia among Edentulous Patients
}

\author{
Lijo Isaac ${ }^{1}$, A. P. Nirmal Raj ${ }^{2}$, Reshma Karkera ${ }^{3}$, R Naveen Reddy ${ }^{4 *}$ \\ ${ }^{1}$ Professor and Head, Department of Prosthodontics, Malabar Dental College and Research Centre Manoor, Edappal, Malappuram (Dist.), INDIA \\ ${ }^{2}$ Professor, Department of Prosthodontics, College of Dental Science \& Hospital, Amargadh, Sihor Taluk, Bhavnagar District, INDIA \\ ${ }^{3}$ Professor, Dept of Prosthodontics, A. J. Institute of Dental Sciences, Mangaluru, Karnataka 575004, INDIA \\ ${ }^{4}$ Assistant Professor, Department of Prosthodontics, College of Dentistry, Jazan, KSA \\ *Email for Correspondence: drnaveenramireddy@ gmail.com
}

\begin{abstract}
Very little studies were done on relationship of the dental status and the nutritional status. The present study was done to study relation between edentulism and the presence of anemia. The study was included of 46 adult patients with edentulism and same numbers of patients were taken as controls. The results were tabulated and analyzed with the help of IBM SPSS statistics 20 using student's $t$ test. The hemoglobin levels were lower in the edentulous patients that that of the control group. The present study had shown that the nutritional status were poor resulting in anemia in case of edentulous patients as compared to control group with the same age group.
\end{abstract}

Key words: Edentulism, Tooth loss, Nutritional status

$10 / 13 / 2016$

Source of Support: None, No Conflict of Interest: Declared

This article is is licensed under a Creative Commons Attribution-NonCommercial 4.0 International License.

Attribution-NonCommercial (CC BY-NC) license lets others remix, tweak, and build upon work non-commercially, and although the new works must also

acknowledge and be non-commercial.

\section{INTRODUCTION}

Edentulism is a debilitating and irreversible condition and is described as the "Final marker of disease burden for oral health". Although the prevalence of complete tooth loss has declined over the last decade, edentulism remains a major disease worldwide, especially among older adults (Emami et al., 2013).

The edentulism has its direct or indirect impact in relation to education, economic circumstances, lifestyle, oral health knowledge and beliefs, and attitudes to dental care (Nowjack-Raymer and Sheiham, 2003). Poor oral health has been shown to have a negative effect on peoples overall health and quality of Life, affecting the mastication, dietary intake and nutritional status (Hamdan and Fahmy, 2014).

The present study was done to evaluate the status of anemia in completely edentulous patients.

\section{Materials AND Methods}

The study was done inclusive of 46 edentulous patients. The study was done after ethical committee approval and after obtaining written consent from all the participants. The same number of patients with the similar age group and sex was taken as control having all of their teeth present. The edentulous patients were belonging to the age group of 45 to 60 years and out of 46 patients, 24 were male patients, while 22 were female patients.

Criteria for anemia: $\mathrm{Hb}<12 \mathrm{gm} \%$ for adolescent (ICMR Bulletin, 1997).

Statistical analysis: The results were tabulated and analyzed with the help of IBM SPSS statistics 20 using student's $t$ test.

\section{RESULTS}

The difference between the hemoglobin levels of the control group and the patients with edentulous state had shown that the hemoglobin levels were higher in the control group and the difference was found to be statistically significant (student's t test, $\mathrm{p}<0.05$ ). 
Table 1: The comparison of the $\mathrm{Hb}$ levels of the control group and the patients with edentulism

\begin{tabular}{|c|c|c|c|c|c|}
\hline Group & Number of patients (n) & Hb levels (Mean \pm SD) & T value & P value & Statistical significance \\
\hline Control group & 46 & $13.2 \pm 1.75 \mathrm{gm} \%$ & 2.4152 & 0.0266 & $<0.05$ \\
\hline Study group & 46 & $11.3 \pm 1.77 \mathrm{gm} \%$ & & & \\
\hline
\end{tabular}

Graph 1: The comparison of the $\mathrm{Hb}$ levels of the control group and the patients with edentulism

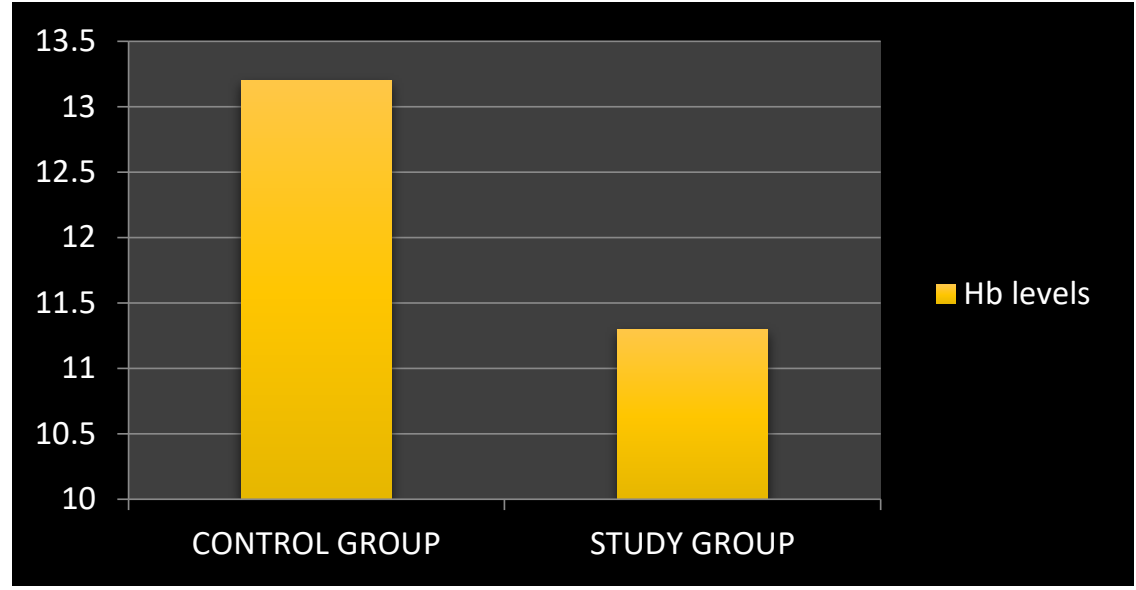

\section{Discussion}

Edentulism is defined as the loss of all permanent teeth and is the terminal outcome of a multifactorial process involving biologic processes (caries, periodontal disease, pulpal pathology, trauma, oral cancer) as well as nonbiologic factors related to dental procedures (access to care, patient's preferences, treatment options etc.) (Hamdan and Fahmy, 2014). Although not life threatening, the complete loss of all teeth, or edentulism, has significant impact on an individual (Hewlett et al., 2015).

Several factors of great relevance to the dentistry area, which may interfere in the intake and selection of foods, are the loss of teeth, use of unsatisfactory dentures, aging and the social-economic-cultural question (Carvalho de Oliveira et al.).

Several studies have shown that edentate elderly consume fewer fruit and vegetables; less dietary fiber, carotene, calcium, and protein; and more cholesterol and saturated fat than do their dentate counterparts. Furthermore, these alterations in dietary intake have been suspected to increase the risk of significant weight loss and possibly of selected systemic diseases such as cancer and cardiovascular disease (Lee et al., 2004).

If we accept that people with significant tooth loss eat fewer fresh fruits, vegetables and meats than fully dentate people, we must next question whether this difference in diet places edentulous individuals at higher risk of malnutrition (Hutton et al., 2002).

In the present study we found that the hemoglobin levels were lower in the edentulous patients that that of the control group. Study by Nowjack-Raymer and Sheiham (2003) has shown that intakes of some nutrient-rich foods and beta carotene, folate, and vitamin C serum levels were significantly lower in denture-wearers.

Extensive tooth loss reduces masticatory performance and affects the choice of food of an individual. Hence edentulous people tend to avoid dietary fiber and often prefer soft foods rich in saturated fats and cholesterols. Thus edentulism is considered to be an indicator of oral health of a person (Nayar et al., 2013).

\section{CONCLUSION}

The present study had shown that there is relation between the edentulism and the nutritional status. The present study results should be validated by doing the present study on large scale.

\section{REFERENCES}

Carvalho de Oliveira TZ, Tânia de Freitas B, Mendes FA, Domingues das Neves F. Risk of malnutrition in completely edentulous individuals. In: Malnutrition in the 21st Century. ISBN 978-1-60021-788-3.

Emami E, Freitas de Souza R, Kabawat M, Feine JS. The Impact of Edentulism on Oral and General Health. Hindawi Publishing Corporation International Journal of Dentistry Volume 2013, Article ID 498305. 
Hamdan EA, Fahmy MM. Socioeconomic factors and complete edentulism for female patients at King Saud University, Riyadh, Saudi Arabia. Tanta Dental Journal 2014; 11: 169e-73e.

Hewlett SA, Yawson AE, Calys-Tagoe BNL, Naidoo N, Martey P, Chatterji S, et al. Edentulism and quality of life among older Ghanaian adults. Hewlett et al. BMC Oral Health 2015; 15(48): 1-9.

Hutton B, Feine J, Morais J. Is There an Association Between Edentulism and Nutritional State? J Can Dent Assoc 2002; 68(3): $182-7$.

ICMR Bulletin. A reappraisal of the iron status indicators. 1997; Vol 27:1

Lee JS, Weyant RJ, Corby P, Kritchevsky SB, Harris TB, Rooks R, Rubin SM, Newman AB. Edentulism and nutritional status in a biracial sample of well functioning, community-dwelling elderly: the Health, Aging, and Body Composition Study. Am J Clin Nutr 2004; 79: 295-302.

Nayar S, Bhuminathan S, Shri Nisha J, Ramesh G, Sujitha K. Edentulism and Public Awareness -An Epidemiological Study. Biomedical \& Pharmacology Journal 2013; 6(1): 77-81.

Nowjack-Raymer RE, Sheiham A. Association of Edentulism and Diet and Nutrition in US Adults. Journal of Dental Research 2003; 82(2): 123-6.

$$
--0 \text {-- }
$$


MJMBR listed in CSE member's journals database

http://www.councilscienceeditors.org/about/members-journals/

Indexed in Google Scholar

https://scholar.google.com/citations?hl=enanduser=JH23W_8AAAAI

MJMBR Following the ICMJE Recommendations (list date 7/1/14)

http://www.icmje.org/recommendations/

\section{RoMEO: This is a RoMEO blue journal}

http:/ / www.sherpa.ac.uk/romeo/search.php?issn=2313-0008

Author's Pre-print: author cannot archive pre-print (ie pre-refereeing)

Author's Post-print: author cannot archive post-print (ie final draft post-refereeing)

Publisher's Version/PDF: author can archive publisher's version/PDF

\section{(c) $(1)(2)$}

This journal is licensed under a Creative Commons Attribution-NonCommercial 4.0 International License. Articles can be read and shared for noncommercial purposes under the following conditions:

- BY: Attribution must be given to the original source (Attribution)

- NC: Works may not be used for commercial purposes (Noncommercial)

This license lets others remix, tweak, and build upon your work non-commercially, and although their new works must also acknowledge you and be non-commercial, they don't have to license their derivative works on the same terms.

License Deed Link: http://creativecommons.org/licenses/by-nc/4.0/

Legal Code Link: http://creativecommons.org/licenses/by-nc/4.0/legalcode

MJMBR uses the CC BY-NC to protect the author's work from misuse. 